\title{
Colicin type 7 produced by majority of Shigella sonnei isolated from Thai patients with diarrhoea
}

\author{
Siriporn Kaewklom ${ }^{1}$, Seksun Samosornsuk ${ }^{2}$, Duangnate Pipatsatitpong ${ }^{2}$, \\ Ratchaneewan Aunpad ${ }^{1}$ \\ ${ }^{1}$ Graduate Program in Biomedical Sciences, Faculty of Allied Health Sciences, Thammasat University, \\ Rangsit Campus, Klonglaung, Pathumthai, Thailand. \\ ${ }^{2}$ Department of Medical Technology, Faculty of Allied Health Sciences, Thammasat University, \\ Rangsit Campus, Klonglaung, Pathumthai, Thailand.
}

Submitted: December 26, 2011; Approved: November 13, 2012.

\begin{abstract}
Thirty one out of 153 strains of Shigella sonnei isolated from Thai patients with diarrhoea showed antibacterial activity against $S$. sonnei by agar well diffusion method. All of them harbor plasmids with the genetic determination of colicin type 7 (Js) gene but without colicin $E$ and colicin $U$ gene. The PCR product obtained from strain 35/44 was shown to be the gene for colicin type 7 lytic protein (cja). The partially purified bacteriocin (PPB) containing colicin type 7 of strain 35/44 was prepared and used for characterization. The antibacterial activity of PPB against a total of 17 selected Gram-positive and Gram-negative bacteria was tested. It was found that PPB of strain 35/44 was active against $E$. coli $\mathrm{O} 157, S$. sonnei and $S$. boydii. The sensitivity of PPB from this strain to proteinase $\mathrm{K}$, trypsin and $\alpha$-chymotrypsin suggests the proteinaceous nature of these antimicrobial substances. Therefore, this isolated bacterium can be regarded as bacteriocin producing bacteria. The bacteriocin produced by this isolated $S$. sonnei was heat stable as evidenced by its ability to maintain the activity at $80{ }^{\circ} \mathrm{C}$ for $60 \mathrm{~min}$. In addition, it was stable within a wide range of $\mathrm{pH}(3-9)$. The molecular weight of colicin type 7 from isolated $S$. sonnei strain 35/44 analyzed by SDS-PAGE was $54.4 \mathrm{kDa}$ composing of at least five subunits. It is to our knowledge; the first report of Thai patients with diarrhoea that S. sonnei isolated from them contained colicin type 7.
\end{abstract}

Key words: Shigella sonnei, colicin type 7, diarrhoea.

\section{Introduction}

Many Gram-negative bacteria such as Shigella, E. coli, Salmonella and Vibrio are common causes of foodborne diseases. Shigella is one of the most common bacterial agents of acute diarrhoea spread through the faecal-oral route, and as few as 100 bacterial cells can be enough to cause an infection. It has been estimated that nearly 165 million of Shigella cases occurred throughout the world with 1.1 million deaths mainly in developing countries (Kotloff et al., 1999). The major cause could be the contamination of Shigella in fresh and processed food. The development of natural food preservatives to be used instead of chemical preservatives in food products has dra- matically increased in recent years. One way is the utilization of bacteriocins produced by bacteria.

Bacteriocins are ribosomally synthesized antimicrobial proteinaceous compounds that are produced by bacteria that usually inhibit closely related species (Klaenhammer 1988). The most extensively studied Gram-negative bacteriocins are colicins from $E$. coli which also serve as a model for ecology, evolution, function, structure and genetic organization of bacteriocin from Gram-negative bacteria nowadays (Cascales et al., 2007). Colicins are high molecular weight toxic proteins that are produced by colicinogenic strains of $E$. coli and some related species of the family Enterobacteriaceae (Smajs and Weinstock 2001). They are usually encoded by colicinogenic plasmids and 
kill other cells by a variety of mechanisms such as membrane permeabilization, nucleic acid degradation or protein synthesis inhibition (Padilla et al., 2006). There are at least 23 colicin types have been described in detail (Smajs and Weinstock 2001). It has been reported that $S$. sonnei, $S$. flexneri, and S. boydii produce colicin (Horak 1994; Padilla et al., 2006; Smajs and Weinstock 2001; Smajs et al., 1997; Smarda et al., 1987; Sousa et al., 2010); however, there are only a few reports on the characterization of bacteriocin from S. sonnei (Smarda et al., 1987; Sousa et al., 2010; Tigyi 2005). The aim of this study was to determine the colicin production by $S$. sonnei strain isolated from Thai patients with diarrhoea and to characterize its properties.

\section{Materials and Methods}

\section{Bacterial strains and culture conditions}

One hundred and fifty three $S$. sonnei strains were isolated from patients with shigellosis in the Kaeng-Khoi district of Saraburi province during May 2000 to April 2003 (Na-ubol et al., 2006). Bacteriocin activity was screened for antibacterial activity against the indicator strain, $S$. sonnei. It was grown in Tryptic soy broth (TSB) at $37^{\circ} \mathrm{C}$ under shaking (200 rpm). Agar was added when needed.

\section{Antibacterial activity assays}

The antibacterial activity of $153 \mathrm{~S}$. sonnei isolated strains was determined by agar well diffusion method (Millette et al., 2007). A $5 \mathrm{~mL}$ nutrient broth was inoculated with single colony of an overnight culture of each isolate and incubated at $37^{\circ} \mathrm{C}$ for $16-18 \mathrm{~h}$ with shaking $(200 \mathrm{rpm})$. Fifty $\mu \mathrm{L}$ of cell-free culture supernatant (CFS) obtained through centrifugation at $8,000 \times \mathrm{g}$ for $20 \mathrm{~min}$ (Sorvall Biofuge, Mandel Scientific, Canada) and sterile by filtration was dropped in a soft agar (1.2\% agar) inoculated with the cell suspension of the indicator strain at a final concentration of ca. $10^{5} \mathrm{cfu} / \mathrm{mL}$. The plates were then incubated at $37^{\circ} \mathrm{C}$ for $16-18 \mathrm{~h}$ and the appearance of clear zones showing the antagonistic activity was observed. The assay for each sample was done in triplicate.

\section{Isolation, purification and analysis of plasmid DNA}

Plasmid DNA from thirty one bacteriocinogenic $S$. sonnei was isolated using GeneJET Plasmid Miniprep Kit (Fermentas). DNA was visualized following electrophoresis in $0.7 \%(\mathrm{w} / \mathrm{v})$ agarose gel in TBE buffer by staining with ethidium bromide $(0.5 \mu \mathrm{g} / \mathrm{mL})$.

\section{PCR Amplification of colicin gene}

Detection of colicin structural genes (colicin 7, colicin E1 and colicin $U$ ) was performed by PCR. The plasmid DNA from forty bacteriocinogenic $S$. sonnei was used as a template. Gene specific primer sequences were designed based on the published colicin gene sequences (Higashi et al., 1986; Smajs and Weinstock 2001; Smajs et al., 1997). The primer sequences for amplification of colicin 7 gene were, forward: 5'-TCT CAA AAT GTT TGG GCT CC-3', and reverse: 5'-CCC TGT CCC ACT GAC ACT TT-3'. The primer sequences for amplification of colicin E1 were, forward: 5'-GGC GGT GGT GGT GGA ACT GG-3', and reverse: 5'-ACA GCC CGG GCC TCT TCA CT-3'. The primer sequences for amplification of colicin U were, forward: 5'-ATG CGC TGC AGG CAC AGG TT-3', and reverse: 5'-GCA TCA GCG GCC CCC AGT TT-3'. Each PCR reaction was performed in a $50 \mu \mathrm{L}$ reaction volume containing $0.2 \mathrm{mM}$ dNTPs (dATP, dGTP, $\mathrm{dCTP}$ and dTTP), $20 \mu \mathrm{M}$ of individual primers, $50 \mathrm{ng}$ of DNA template, $5 \mu \mathrm{L}$ of $10 \mathrm{X}$ PCR buffer and $0.5 \mathrm{U}$ of Taq polymerase enzyme. The final volume was adjusted by adding sterilized distilled water to $50 \mu \mathrm{L}$. The PCR condition was as follow; initial denaturation at $94^{\circ} \mathrm{C}$ for $2 \mathrm{~min}$; followed by 40 cycles of denaturation at $94^{\circ} \mathrm{C}$ for $1 \mathrm{~min}$, annealing at $55^{\circ} \mathrm{C}$ for $1 \mathrm{~min}$, and polymerization at $72{ }^{\circ} \mathrm{C}$ for $1 \mathrm{~min}$; and a final extension at $72{ }^{\circ} \mathrm{C}$ for $5 \mathrm{~min}$. PCR products were separated by electrophoresis on $1.5 \%$ agarose gels and stained with ethidium bromide $(0.5 \mu \mathrm{g} / \mathrm{mL})$. The expected PCR product size of colicin 7 , colicin E1 and colicin $U$ gene are 249, 467 and 570 bp, respectively. The nucleotide sequence of PCR products were sequenced and analyzed with GenBank nucleotide database using Blastn search (http://www.ncbi.nlm.nih.gov/blastn).

\section{Preparation of partially purified bacteriocin (PPB)}

One of the isolated S. sonnei strains 35/44 was selected for further study. Two hundred mL TSB medium was inoculated with $1 \%\left(10^{6} \mathrm{cfu} / \mathrm{mL}\right)$ of an overnight culture of each isolate and incubated at $37^{\circ} \mathrm{C}$ for $16-18 \mathrm{~h}$ with shaking. Following cultivation, cell-free culture supernatant was obtained through centrifugation at $8,000 \mathrm{x}$ g for 20 min (Sorvall Biofuge, Mandel Scientific, Canada) followed by sterile filtration. Ammonium sulfate (103.2 g) was added to the supernatant while stirring to reach $80 \%$ saturation and left overnight at $4{ }^{\circ} \mathrm{C}$. The sample was centrifuged at $8000 \mathrm{x} \mathrm{g}$ for $50 \mathrm{~min}$. Then the supernatant was discarded and the precipitate was dissolved in $5 \mathrm{~mL}$ of sterile distilled water and dialyzed against $1.5 \mathrm{~L}$ of sterile distilled water for $16-18 \mathrm{~h}$. The active supernatant was designated as partially purified bacteriocin or PPB.

\section{Spectrum of inhibitory activity}

PPB was used to assess the antibacterial activity against a total of 17 selected Gram-positive and Gramnegative test bacteria (Table 1) by the agar-well diffusion method (Millette et al., 2007). Equal volume of sterile distilled water was used as control solution. The appearance of the inhibition zone was determined after $18 \mathrm{~h}$ of incubation. 


\section{Enzyme sensitivity, heat and $\mathrm{pH}$ stability}

The PPB was treated at $37^{\circ} \mathrm{C}$ for $1 \mathrm{~h}$ with $1 \mathrm{mg} / \mathrm{mL}$ final concentration of the following enzymes: trypsin, $\alpha$-chymotrypsin and proteinase K (Sigma-Aldrich, USA). After incubation, the reaction mixtures were boiled for $10 \mathrm{~min}$ to inactivate the enzymes and the residual antibacterial activity was measured by agar-well diffusion (Millette et al., 2007). Thermal stability of bacteriocin was investigated by determination of the residual antibacterial activity after incubation of PPB at different temperature ranging from $40-100{ }^{\circ} \mathrm{C}$ for 30 and $60 \mathrm{~min}$, and at $121^{\circ} \mathrm{C}$ for $15 \mathrm{~min}$. To investigate the effect of $\mathrm{pH}$, antibacterial activity was measured following the $\mathrm{pH}$ adjustment of the bacteriocin with $0.1 \mathrm{~N} \mathrm{NaOH}$ or $0.1 \mathrm{~N} \mathrm{HCl}$ and incubation at $4{ }^{\circ} \mathrm{C}$ for $1 \mathrm{~h}$.

\section{Molecular weight determination}

The molecular weight of bacteriocin from S. sonnei strain 35/44 were determined by glycine SDS-PAGE with $5 \%$ stacking gel and 12\% separating gel. The first half of the gel (protein gel) was stained with PageBlue Protein staining solution (Fermentas, USA) whereas another half of the gel (activity gel) was washed in sterile distilled water for $30 \mathrm{~min}$ and overlaid with TSBYE $(0.8 \%$ agar $)$ seeded with $0.1 \%$ (v/v) S. sonnei strain 44/44 (0.5 McFarland) and incubated at $37^{\circ} \mathrm{C}$ for $16-18 \mathrm{~h}$. The formation of clear halo or inhibition zone was observed and compared with protein gel.

\section{Results}

Among 153 strains of $S$. sonnei isolated from Thai patients, thirty one strains showed antibacterial activity against $S$. sonnei by agar well diffusion method. It was found that plasmid extracted from all of isolated strains of bacteriocinogenic $S$. sonnei gave PCR product with the expected size of $249 \mathrm{bp}$ with primer specific to colicin type 7 (Js) gene (Figure 1). By DNA sequencing, the PCR product obtained from strain $35 / 44$ showed $99 \%$ identity to complete sequence plasmid ColJs, plasmid pScol 7 and complete codons of colicin type 7 ( $c j a)$ lytic protein of $S$. sonnei. There were no PCR products obtained from primer specific to colicin $E$ and colicin $U$ (Figure 1). The antimicrobial activity spectrum of partially purified bacteriocin (PPB) from isolated S. sonnei strain 35/44 against 17 test microorganisms was examined by agar diffusion method. It showed antibacterial activity against only Gram-negative test bacteria (Table 1). The PPB prepared from two isolated strains was tested for sensitivity to various proteolytic enzymes (trypsin, $\alpha$-chymotrypsin and proteinase $\mathrm{K}$ ), a key criterion for bacteriocin characterization. The complete inactivation was observed after treatment with all proteolytic enzymes (Table 2). Temperature stability experiment revealed that PPB from isolated $S$. sonnei strain $35 / 44$ was completely stable at temperature up to $80{ }^{\circ} \mathrm{C}$ for $60 \mathrm{~min}$ (Table 2). With regard to $\mathrm{pH}$ stability, antibacterial activity

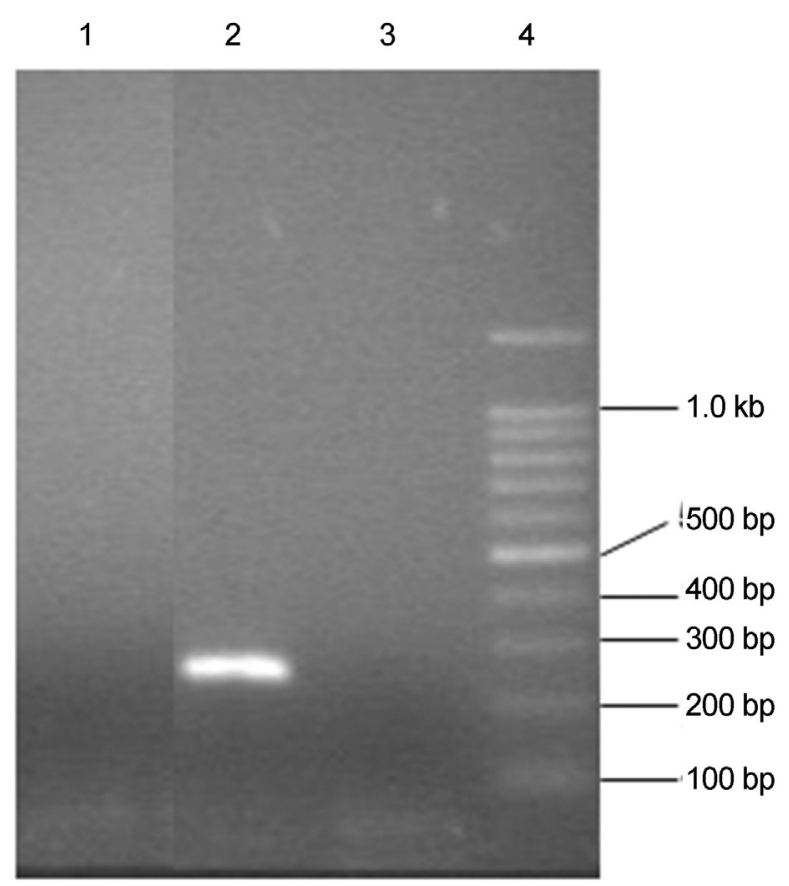

Figure 1 - PCR products obtained from $S$. sonnei strain 35/44. Lane 1: amplified product of colicin $U$ gene; Lane 2: amplified product of colicin 7 gene; Lane 3: amplified product of colicin E gene; Lane 4: 100 bp DNA marker.

of PPB of strain 35/44 was maintained more than $90 \%$ residual activity within the $\mathrm{pH}$ range of 3.0-9.0 (Table 2). The molecular weight of bacteriocin from isolated $S$. sonnei was determined by SDS-PAGE analysis of PPB. As shown in Figure 2, a single protein band with clear halo revealed a bacteriocin activity. The molecular weight of bacteriocin from isolated $S$. sonnei strain $35 / 44$ was determined as $54.4 \mathrm{kDa}$.

\section{Discussion}

A variety of bacteriocins have attracted attention for their potential applications as natural and safe food preservatives due to their specificity and sensitivity. In this study, thirty one out of 153 strains of $S$. sonnei isolated from Thai patients with diarrhoea showed antibacterial activity against $S$. sonnei by agar well diffusion method. Only the $S$. flexneri strains isolated from dysenteric diarrhoea produced bacteriocin active against several $E$. coli and non-bacteriocin producing $S$. flexneri strains (Padilla et al., 2006). Bacteriocins have been reported to be produced by several enteric bacteria including S. sonnei, S. flexneri, and $S$. boydii. They are usually designated as colicins (Horak 1994; Padilla et al., 2006; Smajs and Weinstock 2001; Smajs et al., 1997; Smarda et al., 1987; Sousa et al., 2010). Colicin genes are found mostly in colicinogenic plasmids of Gram-negative E. coli (Cascales et al., 2007). It was demonstrated that all of thirty one isolated strains of bacteriocinogenic $S$. sonnei harbor plasmids with the genetic 
Table 1 - Inhibitory spectrum of PPB from isolated S. sonnei strain 35/44.

\begin{tabular}{|c|c|c|c|c|}
\hline Strain & Source* & Growth medium** & Incubation temperature & Inhibitiory activity \\
\hline \multicolumn{5}{|l|}{ Gram-positive } \\
\hline Bacillus cereus & MT & TSA & $37^{\circ} \mathrm{C}$ & \\
\hline Bacillus pumilus & WAPB4 & TSA & $37^{\circ} \mathrm{C}$ & - \\
\hline Bacillus subtilis & ATCC6633 & TSA & $37^{\circ} \mathrm{C}$ & - \\
\hline Bacillus sphearicus & SOPB1 & TSA & $37^{\circ} \mathrm{C}$ & - \\
\hline Enterococcus sp. & MT & BHI & $37^{\circ} \mathrm{C}$ & - \\
\hline Vancomycin resistant Enterococcus (VRE) & DMST4737 & BHI & $37^{\circ} \mathrm{C}$ & - \\
\hline Staphylococcus aureus & MT & TSA & $37^{\circ} \mathrm{C}$ & - \\
\hline Methicillin resistant & DMST5199 & TSA & $37^{\circ} \mathrm{C}$ & - \\
\hline S. aureus (MRSA) & & & $37^{\circ} \mathrm{C}$ & \\
\hline Listeria monocytogenes & MT & MRS & $37^{\circ} \mathrm{C}$ & - \\
\hline \multicolumn{5}{|l|}{ Gram-negative } \\
\hline Escherichia coli & O157 SW4 & TSA & $37^{\circ} \mathrm{C}$ & ++ \\
\hline Ampicillin resistant E.coli (ARE) & DMST19374 & TSA & $37^{\circ} \mathrm{C}$ & - \\
\hline Salmonella typhi & MT & TSA & $37^{\circ} \mathrm{C}$ & - \\
\hline Salmonella typhimurium & MT & TSA & $37^{\circ} \mathrm{C}$ & - \\
\hline Shigella dysenteriae & MT & TSA & $37^{\circ} \mathrm{C}$ & - \\
\hline Shigella flexneri & MT & TSA & $37^{\circ} \mathrm{C}$ & - \\
\hline Shigella boydii & MT & TSA & $37^{\circ} \mathrm{C}$ & + \\
\hline Shigella sonnei & MT & TSA & $37^{\circ} \mathrm{C}$ & ++ \\
\hline
\end{tabular}

*ATCC, American Type Culture Collection; MT, Department of Medical Technology, Thammasat University, Thailand; DMST, Department of Medical Sciences, Ministry of Public Health Thailand.

${ }^{* *}$ TSA, Tryptic Soy Agar; MRS, de Man, Rogosa and Sharpe; BHI, Brain Heart Infusion.

$(-)$ no inhibition, (+) mild inhibition (1-5 mm of inhibition zone), (++) strong inhibition (more than $5 \mathrm{~mm}$ of inhibition zone).

determination of colicin type 7 gene but without colicin $E$ and colicin $U$ gene. The PCR product obtained from strain 35/44 was shown to be the gene for colicin type 7 (cja) lytic protein. The presence of a DTLSN pentapeptide motive in

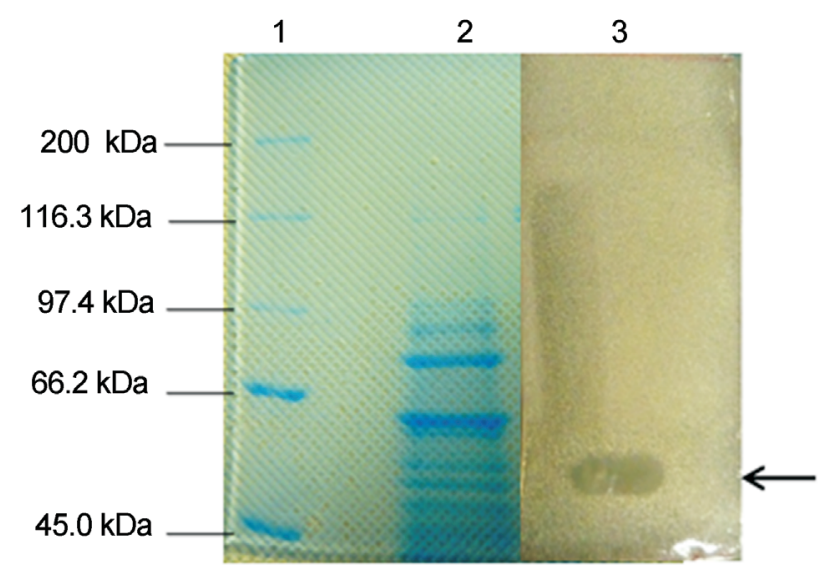

A

B

Figure 2 - SDS PAGE analysis of PPB prepared from $S$. sonnei strain 35/44 (A) Coomassie brilliant blue stained gel (B) The activity gel shows the clear zone (arrow) after overlaid with TSA $(0.8 \%$ agar) seeded with $S$. sonnei and incubated overnight. Lane 1: Broad range protein molecular weight marker (Biorad); lane 2 and 3: PPB of strain 35/44. translated polypeptide of strain 35/44 suggests that it could be imported to sensitive cells via the TonB transport system (Tigyi et al., 2005). The 5.2-kb ColJs plasmid of a colicinogenic strain of $S$. sonnei (colicin type 7) contained three genes encoding $10.4 \mathrm{kDa}$ Colicin Js activity polypeptide, $14.3 \mathrm{kDa}$ Colicin Js immunity peptide and 7.5 kDa Colicin Js releasing peptide (Smajs and Weinstock 2001). Colicin gene clusters are usually composed of a colicin gene, which encodes the toxin; an immunity gene, which encodes a protein conferring specific immunity to the producer cell; and a lysis gene, which encodes a protein involved in colicin release through lysis of the producer cell (Riley and Wertz 2002). The absence of neither colicin $E$ nor colicin $U$ among these isolated strains indicated that the bacteriocin produced by $S$. sonnei strain 35/44 is colicin type 7 . Therefore $S$. sonnei isolated strain $35 / 44$ can be regarded as colicin type 7 producing bacteria.

The partially purified bacteriocin (PPB) prepared from $S$. sonnei strain 35/44 was active against $E$. coli $\mathrm{O} 157$, $S$. sonnei and $S$. boydii. The narrow target range of colicins was due to the presence of specific receptors at the surface of the sensitive strains (Cascales et al., 2007). Nine out of $16 S$. sonnei strains isolated from children with diarrhoea exhibited isoantagonism and heteroantagonism against $S$. flexneri and diarrhoeagenic E. coli by the overlay method 
Table 2 - Effect of enzymes, temperature and $\mathrm{pH}$ on PPB from S. sonnei strain $35 / 44$.

\begin{tabular}{|c|c|}
\hline Treatments and conditions & Residual activity (\%) \\
\hline None (control) & 100 \\
\hline \multicolumn{2}{|l|}{ Enzyme treatment } \\
\hline Trypsin & 0 \\
\hline$\alpha$-chymotrypsin & 0 \\
\hline Proteinase K & 0 \\
\hline \multicolumn{2}{|l|}{ Temperature } \\
\hline $40^{\circ} \mathrm{C}, 30 \mathrm{~min}$ & 100 \\
\hline $40^{\circ} \mathrm{C}, 60 \mathrm{~min}$ & 92 \\
\hline $60^{\circ} \mathrm{C}, 30 \mathrm{~min}$ & 95 \\
\hline $60^{\circ} \mathrm{C}, 60 \mathrm{~min}$ & 83 \\
\hline $80^{\circ} \mathrm{C}, 30 \mathrm{~min}$ & 83 \\
\hline $80^{\circ} \mathrm{C}, 60 \mathrm{~min}$ & 66 \\
\hline $100{ }^{\circ} \mathrm{C}, 30 \mathrm{~min}$ & 0 \\
\hline $100^{\circ} \mathrm{C}, 60 \mathrm{~min}$ & 0 \\
\hline $121^{\circ} \mathrm{C}, 15 \mathrm{~min}$ & 0 \\
\hline \multicolumn{2}{|l|}{$\mathrm{pH}$} \\
\hline 3.0 & 100 \\
\hline 4.0 & 100 \\
\hline 5.0 & 100 \\
\hline 6.0 & 100 \\
\hline 7.0 & 92 \\
\hline 8.0 & 92 \\
\hline 9.0 & 92 \\
\hline
\end{tabular}

(Sousa et al., 2010). S. sonnei colicin 7 (Scol7) is a bacteriocin acting only on certain dysentery-causing bacteria, like enteroinvasive Escherichia coli, S. sonnei or S. boydii (Tigyi et al., 2005).

The sensitivity of PPB from strain 35/44 to proteinase $\mathrm{K}$, trypsin and $\alpha$-chymotrypsin suggests the proteinaceous nature of these antimicrobial substances. Therefore, this isolated bacterium can be regarded as bacteriocin producing bacteria. The colicin from this isolated $S$. sonnei was heat stable as evidenced by its ability to reserve the activity at $80{ }^{\circ} \mathrm{C}$ for $60 \mathrm{~min}$. In addition, it was stable within a wide range of $\mathrm{pH}$ (3-9). The $46 \mathrm{kDa}$ colicin Js produced by $S$. sonnei is unstable at $\mathrm{pH} 8.0$ and at the temperature of $70{ }^{\circ} \mathrm{C}$ (Smarda et al., 1987). The heat stable property was normally observed in bacteriocin from Gram-positive Bacillus sp. such as pumilicin 4 from B. pumilus (Aunpad and Na-Bangchang 2007) but rarely found in Gram-negative bacteria. The stability of bacteriocin from this isolated $S$. sonnei at high temperature and over a wide range of $\mathrm{pH}$ indicates the potential application in agro-industries as it could preserve its activity at extreme conditions.

The molecular mass of colicin from isolated $S$. sonnei strain 35/44 was $54.4 \mathrm{kDa}$. Colicins have been purified and found to be proteins of high molecular mass ranging from 40 to $80 \mathrm{kDa}$ (Cascales et al., 2007). There are only two reports on molecular mass determination of colicin from $S$. sonnei which are $10.4 \mathrm{kDa}$ colicin Js (Smajs and Weinstock 2001 ) and $11.2 \mathrm{kDa}$ colicin 7 (Tigyi et al., 2005). These are in good agreement with previous estimations for their subunit but the molecular filtration experiments suggest a multimeric structure of at least $50 \mathrm{kDa}$ (Tigyi et al., 2005). The colicin type 7 in $S$. sonnei strain 35/44 might be composed of at least five subunits. It is to our knowledge; the first report of Thai patients with diarrhoea that $S$. sonnei isolated from them contained colicin type 7 .

\section{Acknowledgments}

This work was supported by grants from Higher Education Research Promotion and National Research University Project of Thailand, Office of the Higher Education Commission and National Research Council of Thailand.

\section{References}

Aunpad R, Na-Bangchang K (2007) Pumilicin 4, a novel bacteriocin with anti-MRSA and anti-VRE activity produced by newly isolated bacteria Bacillus pumilus strain WAPB4. Curr Micobiol 55:308-313.

Cascales E, Buchanan SK, Duche D, Kleanthous C, Lloubes R, Postle K, Riley M, Slatin S, Cavard D (2007) Colicin biology. Microbiol Mol Biol Rev 71:158-229.

Higashi M, Hata M, Hase T, Yamaguchi K, Masamune Y (1986) The nucleotide sequence of cea and the region of origin of plasmid pKY-1. J Gen Appl Microbiol 32:433-442.

Horak V (1994) Seventy colicin types of Shigella sonnei and an indicator system for their determination. Zentralbl Bakteriol 281:24-29.

Klaenhammer TR (1988) Bacteriocins of lactic acid bacteria. Biochemie 70:337-349.

Kotloff KL, Winickoff JP, Inanoff B, Clemens JD, Swerdlow DL, Sansonetti PJ, Adak GK, Levine MM (1999) Global burden of Shigella infections: implications for vaccine development and implementation of control Strategies. Bull World Health Organ 77:651-666.

Millette M, Dupont C, Archambault D, Lacroix M (2007) Partial characterization of bacteriocins produced by human Lactococcus lactis and Pediococcus acidilactici isolates. J Appl Microbiol 102:274-282.

Na-ubol M, Samosornsuk S, Von Seidlein L, Tapchaisri P, Ali M, Clemens JD, Chaicumpa W (2006) Molecular characteristics of Shigella spp. isolated from patients with diarrhoea in a new industrialized area of Thailand. Epidemiol Infect 134:997-1003.

Padilla C, Lobos O, Brevis P, Abaca P, Hubert E (2006) Plasmid-mediated bacteriocin production by Shigella flexneri isolated from dysenteric diarrhoea and their transformation into Escherichia coli. Lett Appl Microbiol 42:300-303.

Riley MA, Wertz JE (2002) Bacteriocins: evolution, ecology, and application. Ann Rev Microbiol 56:117-137.

Smajs D, Pilsl H, Braun V (1997) Colicin U, a novel colicin produced by Shigella boydii. J Bacteriol 179:4919-428. 
Smajs D, Weinstock GM (2001) Genetic organization of plasmid ColJs, encoding colicin Js activity, immunity, and release genes. J Bacteriol 183:3949-3957.

Smarda J, Petrzelova J, Vyskot B (1987) Colicin Js of Shigella sonnei: classification of type colicin 7. Zentralbl Bakteriol Mikrobiol Hyg A 263:530-540.

Sousa MÂB, Mendes EN, Apolonio ACM, Farias LDM, Magalhaes PP (2010) Bacteriocin production by Shigella sonnei isolated from faeces of children with acute diarrhoea. APMIS 118:125-135.

Tigyi Z, Kispál G, Pál T (2005) Identification of the plasmid and the structural gene of colicin type 7 of Shigella sonnei. Acta Biol Hung 56:359-373.

All the content of the journal, except where otherwise noted, is licensed under a Creative Commons License CC BY-NC. 